\title{
Microscopy methods applied to research on cyanobacteria
}

\author{
M. Hernández Mariné, E. Clavero \& M. Roldán \\ Unitat de Botànica, Facultat de Farmàcia, Universitat de Barcelona, Av Joan XXIII s/n, Barcelona E-08028. \\ E-mail: marionahernandez@ub.edu,mroldan@farmacia.far.ub.es, eclavero@farmacia.far.ub.es
}

\begin{abstract}
Several techniques for microscopic examination of cyanobacteria were reviewed. These included transmission electron microscopy (TEM), scanning electron microscopy (SEM) and confocal laser scanning microscopy (CLSM). Advantages and examples of individual techniques are presented. Their combination provides an efficient way for determining the presence and viability of cyanobacteria, characterization of taxa, observation of cytomorphology and definition of 3-D structure within communities.
\end{abstract}

Keywords: cyanobacteria, transmission electron microscopy, scanning electron microscopy, laser scanning microscopy

\section{RESUMEN}

Se revisan técnicas para el examen microscópico de las cianobacterias. Se incluyen la microscopía electrónica de barrido (SEM), la microscopía electrónica de transmisión (TEM) y la microscopía de barrido láser confocal (CLSM). Se presentan ventajas y ejemplos de cada una de las técnicas. Su combinación proporciona herramientas eficientes para la identificación y caracterización de las cianobacterias. Con su uso se puede comprobar su presencia y viabilidad y definir la citomorfología y la estructura tridimensional de las comunidades que forman.

Palabras clave: cianobacterias, microscopía electrónica de barrido, microscopía electrónica de transmisión, microscopía de barrido láser confocal

\section{INTRODUCTION}

Cyanobacteria are abundant throughout the world and contribute significantly to global primary productivity from which picoplanktonic marine and aridland terrestrial components account for a large proportion (García-Pichel et al. 2003). The advent of the electron microscopy (history reviewed by McMullan, 1995) revealed that bluegreen algae were bacteria, presenting a welldefined submicroscopic organization with a lacking membrane-bound organelles. Their cells are surrounded by a more or less defined exopolysaccharide covering and a cell envelope of Gramnegative type. Pores of different sizes, orderly arranged or not, perforate the cell wall. What differences them from other prokaryotes is their ability to perform oxygenic photosynthesis, localized in the thylakoid membranes. Thylakoids consist of a double unit membrane enclosing an intrathylakoidal space and their arrangement is characteristic of groups of strains. Thylakoids support two membrane-bound protein complexes, photosystem I (PSI) and photosystem II (PSII), which contain chlorophyll-binding subunits functioning as an internal antenna. In addition, there are rows of phycobilisomes on the thylakoid membrane that act as peripheral antenna systems.

The microscopy techniques most frequently used to determine the diversity of microorganisms in terms of morphology, ecology and physiological adaptations include, scanning electron microscopy (SEM), transmission electron microscopy (TEM) and confocal laser scanning microscopy (CLSM), apart from the classical light microscopy. 

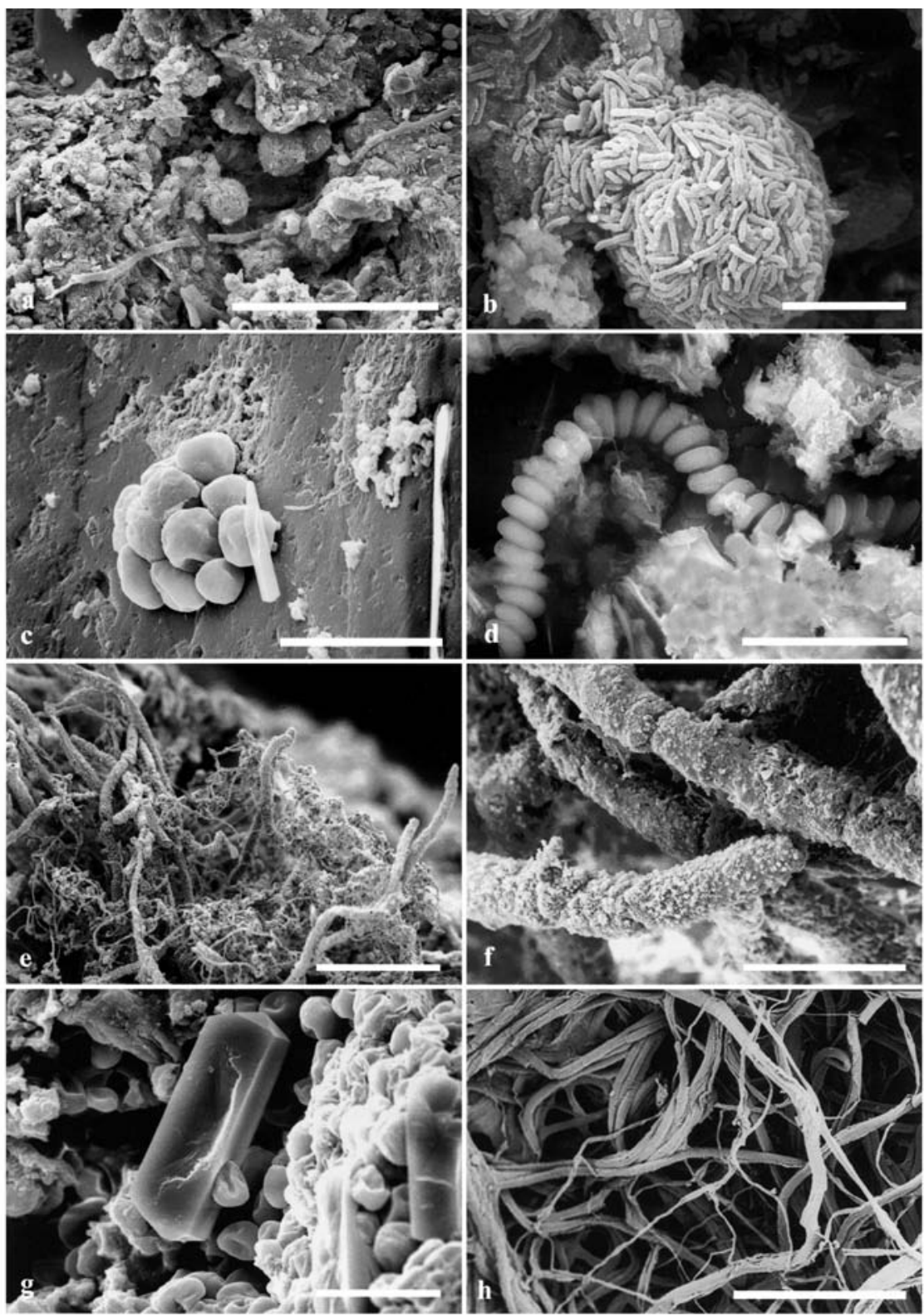

Figure1. Scanning electron photomicrographs. a, b, colonisation inside gypsum crevices. Air drying. a, global view. Scale bar $=50 \mu \mathrm{m}$. $\mathbf{b}$, high magnification of microscopic colonies of Synechococcus sp. Scale bar $=5 \mu \mathrm{m}$. c, small colony of Chroococcus sp. developed on limestone. Conventional chemical fixation. Scale bar $=10 \mu \mathrm{m}$. d, Halospirulina sp. from hipersaline microbial mats. Chemical fixation with $2 \%$ glutaraldehyde added to the hipersaline water. Scale bar $=10 \mu \mathrm{m}$. e,f, biofilm on a calcareous stone surface. It consisted of Scytonema julianum and Leptolyngbya sp. Freeze fixation followed by freeze-drying and critical point drying. e, global view. Scale bar $=200 \mu \mathrm{m}$. f, high magnification of calcified filaments of $S$. julianum with triradiate calcite crystals. Scale bar $=50 \mu \mathrm{m}$. g, rod-shaped cyanobacteria boring a calcite crystal. Scale bar $=10 \mu \mathrm{m}$. h, biofilm growing on plaster built by erected filaments of Leptolyngbya sp. Prefixation in acrolein vapour followed by addition of osmium tetroxide vapour and air drying. Scale bar $=50 \mu \mathrm{m}$. Microfotografias de barrido. $a$, $b$, colonización en el interior de grietas en yesos. Secado al aire. a, visión de conjunto. Escala $=50 \mu \mathrm{m}$. b. aumento de las colonias microscópicas de Synechococcus sp. Escala $=5 \mu m . c$, pequeñas colonias de Chroococcus sp, sobre piedra calcárea. Fijación química convencional. Escala $=10 \mu m$. d, Halospirulina sp. procedente de tapetes microbianos hipersalinos. Escala $=10 \mu \mathrm{m}$. e, $\mathrm{f}$, biofilm sobre piedra calcárea . Formado por Scytonema julianum y Leptolyngbya sp. Fijación mediante congelación seguida de desecado a bajas temperaturas. e, visión de conjunto. Escala $=200 \mu \mathrm{m} . \boldsymbol{f}$, aumento de los filamentos calcificados $\mathrm{S}$. julianum, recubiertos de agujas trirradiadas de calcita. Escala $=50 \mu \mathrm{m}$. $\mathrm{g}$, cianobacteria cocal perforando un cristal de calcita. Escala $=10 \mu \mathrm{m} . \boldsymbol{h}$, biofilm sobre mortero formado por filamentos erectos de Leptolyngbya sp. Prefijación con vapores de acroleina seguidos de vapores de osmio y secado al aire. Escala $=50 \mu m$. 
We illustrate a few practical examples, among the great variety of these techniques, to survey cyanobacterial specimens and to determine their intrinsic features. Protocols may require modifications according to organism characteristics.

\section{SCANNING ELECTRON MICROSCOPY (SEM)}

SEM is used to examine surface topology and distribution of specimens as well as relationship among organisms at a high magnification.

Conventional SEM preparation techniques include air drying; chemical fixation followed by critical point drying or freeze fixation followed by freeze-drying and critical point dried. A general overview of them is found in Goldstein et al. (1981) and Hyatt (1989).

A standard procedure includes chemical fixation with $2 \%$ glutaraldehyde (1,5-glutar-di-aldehyde) in a $0.1 \mathrm{M}$ cacodylate buffer overnight, dehydratation in ethanol and critical point dried. The conductivity of biological material may be increased by the impregnation of the whole material with heavy metal salts. Afterwards, specimens are placed on stubs and coated with carbon or gold sputtered. For samples prone to collapse when submerged in liquid medium, a prefixation in acrolein vapour followed by addition of osmium tetroxide vapour results in adequate preservation of the three- dimensional structures (Hernández-Mariné et al., 2001). Small stones or filters may also be mounted on the stubs with a biadhesive tape and coated.

Clean samples or calcareous investments work well and the procedure is especially helpful for calcite crystals deposited on sheaths or any outer surface (Fig. 1f). However, as biological material, cyanobacteria tend to be susceptible to dehydration. Sheaths and mucilaginous outer layers may be condensed or blurry the surface of the specimens. Examples of the above protocols are shown in Figure 1.

Other types of SEM (not shown) overcome some of the processing inconveniences of conventional SEM. For example, Environmental
Scanning Electron Microscopy allows the observation of fresh samples at low magnification without modification or preparation (Urzi \& Albertano 2001). On the other hand, low temperature scanning electron microscopy (LTSEM), allows the observation of criofractured samples without further process or alteration (Ascaso et al. 2002).

\section{TRANSMISSION ELECTRON MICROSCOPY (TEM)}

TEM provides morphological information about the size, shape and arrangement of organelles inside the cells and the relationship among microorganisms in areas a few nanometers in diameter. A beam of electrons is focused through the sample, producing a map of light and dark areas, which depends on the disposition of heavy metals absorbed selectively in the sample.

Chemical fixation is the most widely used method to preserve biological specimens for TEM. General fixation and embedding methods have been described elsewhere (Hayat, 1989, Bettarel et al., 2000). Samples must be in excellent conditions prior fixation and their ionic strength taken into account, unless the observation of some kind of damage is wanted. For non saline samples 2\% glutaraldehyde in $0,1 \mathrm{M}$ cacodylate buffer and post-fixation with $1 \%$ osmium tetroxide in the same buffer yield acceptable results. Saline samples, that have higher osmolality, may be fixed with a mixture of $2 \%$ glutaraldehyde and variable concentration of formaldehyde solution, according to the osmolarity of the medium or the salinity. Next steps are dehydration, embedding in resin, and sectioning. Sections are stained with heavy metals ex. with $2 \%$ uranyl acetate and lead citrate.

Sometimes the chemical fixation is unsatisfactory. This is mainly revealed by a collapsed cytoplasm. In such a case, or when immunocytochemical and microanalytical studies must be performed, a rapid freeze fixation followed by freeze substitution that replaces cellular water at low temperatures is helpful (Quintana, 1994; Porta et al., 2000). Both methods are appropri- 

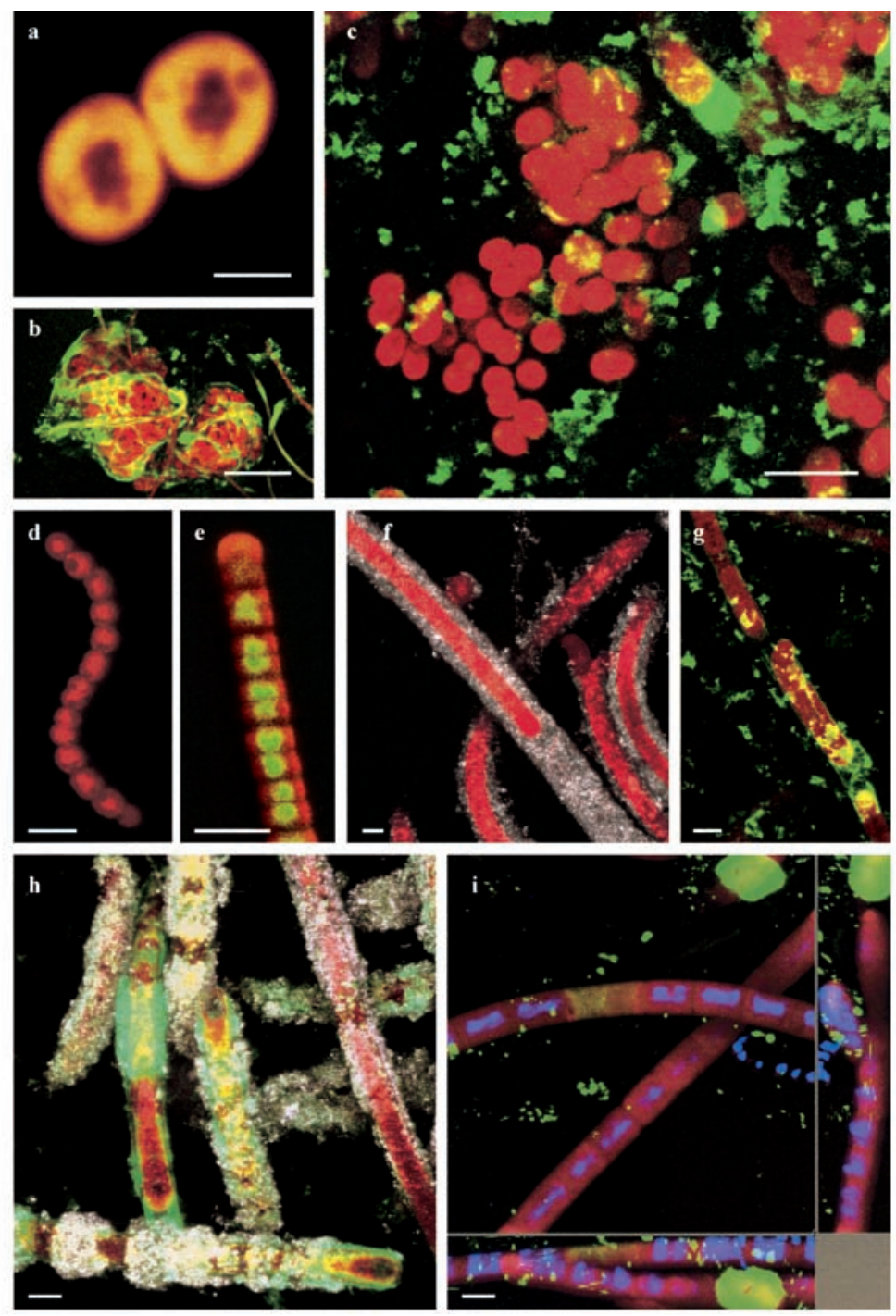

Figure 2. Confocal Laser Scanning photomicrographs. a, Cyanothece PCC 8303, xy single optical thin section. Pigment fluorescence, mainly located at the cell periphery, provides evidence of the thylakoid arrangement. Scale bar $=1 \mu \mathrm{m}$. b, Aphanothece sp. from hypogean habitats. Two-channel (pigment fluorescence in red and EPS in green) maximum intensity projection. Scale bar $=10 \mu \mathrm{m}$. c, Thin biofilm of Gloecapsopsis sp. from hypogean habitats. Two-channel (pigment fluorescence in red and EPS in green) maximum intensity projection. Scale bar $=5 \mu \mathrm{m}$. d, filament of Nostoc sp, $x y$ single optical thin section of pigment fluorescence. Scale bar $=10 \mu \mathrm{m}$. e, Crinalium PCC 9333, single section. In dividing cells the nucleoid figures depends on the stage of the division. Two-channel (pigment fluorescence in red and DNA (SYTOX Green) in green)). $\mathrm{f}, \mathrm{g}, \mathrm{h}, \mathrm{i}$, Scytonema julianum from limestone caves. Scale bar $=5 \mu \mathrm{m}$. f, two-channel (pigment fluorescence in red and reflection image in white) maximum intensity projection, showing the calcite needles. Scale bar $=10 \mu \mathrm{m}$. $\mathbf{g}$, false branching by trichome fragmentation and lateral protusion. Two-channel (pigment fluorescence in red EPS in green) maximum intensity projection. Scale bar $=10$ $\mu \mathrm{m}$. $\mathbf{h}$, three-channel maximum intensity projection (pigment fluorescence in red and EPS in green and calcite needles in white). Scale bar $=$ $10 \mu \mathrm{m}$. i, three-dimensional extended focus projections in $x-y, x-z$ and $y-z$ views, bilinear interpolated $x-y$ CLSM sections in the $z$-direction of the biofilm (pigment fluorescence in red, DNA (Hoechst 33258) in blue and EPS in green). Scale bar $=10 \mu \mathrm{m}$. Microfotografias de CLSM. a, Cyanothece PCC 8303, sección óptica xy. La fluorescencia de los pigmentos, mayoritariamente localizada en la periferia de la célula, evidencia la disposición de los tilacoides. Escala $=1 \mu \mathrm{m}$. $\boldsymbol{b}$. Aphanothece $s p$. de hábitats hipogeos. Proyección de intensidad máxima con doble canal (fluorescencia de los pigmentos en rojo y EPS en verde). Escala $=10 \mu \mathrm{m}$. c , biofilm de Gloecapsopsis sp. procedente de hábitats hipógeos. Proyección de intensidad máxima con doble canal (fluorescencia de los pigmentos en rojo y EPS en verde). Escala $=5 \mu$ m. d, filamento de Nostoc sp, sección óptica xy de la fluorescencia de pigmentos. Escala = $10 \mu \mathrm{m}$. e, Crinalium PCC 9333, sección única. Las figuras de los nucleoides dependen del estado de división. Doble canal (fluorescencia de los pigmentos en rojo y ADN (SYTOX Green) en verde)). $f$, g, $h$, $i$, Scytonema julianum procedente de cuevas calcáreas. Escala $=5 \mu \mathrm{m}$. $\boldsymbol{f}$, Proyección de intensidad máxima con doble canal (fluorescencia de los pigmentos en rojo y reflexión en blanco), mostrando las agujas de calcita. Escala $=10 \mu \mathrm{m} . \mathrm{g}$, Falsa ramificación por fragmentación del tricoma y protusión lateral. Proyección de intensidad máxima con doble canal (fluorescencia de los pigmentos en rojo y EPS en verde). Escala $=10 \mu \mathrm{m}$. $\boldsymbol{h}$, Proyección de intensidad máxima con triple canal (fluorescencia de los pigmentos en rojo, EPS en verde y agujas de calcita en blanco). Escala $=10 \mu \mathrm{m}$. i, Proyección tridimensional "extended focus" en planos $x-y, x-z$ and $y-z$, interpolación bilinear de las secciones $x-y$ de CLSM en dirección z de un biofilm (fluorescencia de los pigmentos en rojo, ADN (Hoechst 33258) en azul y EPS en verde). Escala $=10 \mu \mathrm{m}$. 
ate to localise chemicals or organules at the subcellular level, using cytochemical stains.

Examples of cell wall layers and porefields, exopolysaccharide covering and sheath structure, cellular division behaviour, intercellular relationships and thylakoid arrangement, using the above described protocols, are shown in Figure 2.

\section{CONFOCAL LASER SCANNING MICROSCOPY (CLSM)}

CLSM is a tool for 3-D localization of fluorescent organisms or items dyed with fluorescent labels. The technique provides an efficient way to determine the presence, the viability and the spatial organization of specific organisms. It offers the possibility for non-invasive optical sectioning by substracting out-of-focus planes of the image. It allows the in situ observations, that is, to examine the surface and the in depth structure of the sample with minimal preparation and without disturbing the structure (Neu \& Lawrence, 1997; Roldán et al., 2004).

Advantages are the inherent specificity and sensitivity of fluorescent probes and labelling protocols (Haugland, 1999). CLSM has become a standard tool and its capabilities and use for biological applications are summarized elsewhere (Pawley, 1995). We used a combination of natural pigment fluorescence and fluorescence probes for imaging the in situ 3D structure of cyanobacteria and their extracellular polymeric substances (EPS).

The CLSM equipments provide series of thin optical sections of the sample. Optical sections are $2 \mathrm{D}$ images obtained at different intervals ( $\mathrm{z}$ step) along the optical axis. The $\mathrm{z}$ profile is obtained by setting the start position above the sample and the stop position below the layers of interest. CLSMs are equipped with different lasers and detection channels. Laser light sources are monochromatic and the most usual include argon (488 and $514 \mathrm{~nm}$ ), argon-krypton (488, 568, and $647 \mathrm{~nm})$, helium-neon $(543,596$, and $633 \mathrm{~nm}$ ), and ultraviolet (UV)-argon (351$364 \mathrm{~nm}$ ) excitation laser beams.
Samples must be fluorescent to be observed in the CLSM. The cyanobacterial photosynthetic pigments, chlorophyll $a$ and phycobilins, have an inherent fluorescence at 543 and $633 \mathrm{~nm}$ excitation and 590-800 $\mathrm{nm}$ emission. To target other specific elements many fluorescent dyes and labels can be used. We use Hoechst 33258 to localize nucleoids, in living or death cells, that fluoresce in blue when excited by ultraviolet light (351 and $364 \mathrm{~nm}$ ) and SYTOX Green S7020 that fluoresce in green when excited by blue light (488 nm). SYTOX Green has a high affinity for nucleic acids, but cannot cross the membranes of the living cells which must be fixed before observation. Either glutaraldehyde in $0.2 \mathrm{M}$ cacodylate buffer $(\mathrm{pH}=7.2)$ or $4 \%$ paraformaldehyde in phosphate buffered saline (PBS) solution $0.15 \mathrm{M}(\mathrm{pH}=7.4)$ may be used for fixation. However, glutaraldehyde must be used with caution due to its inherent fluorescence in a wide range of wavelengths.

EPS are revealed with the carbohydrate recognising lectin Concanavalin-A (Con-A from Canavalia ensiformis) or Wheat Germ Agglutinin (WGA from Triticum vulgaris), both need to be conjugated with a fluorophore such as Alexa Fluor 488, among other labels (all fluorescent stains from Molecular Probes, Inc. Leiden). To avoid interference or overlapping of labels that fluoresce in the same wavelengths of pigments, samples are first fixed and then they are discoloured with a 3:1 mixture of ethanol and glacial acetic acid and rinsed in distilled water.

Reflection image (grey channel, excitation at $488 \mathrm{~nm}$ and emission at 480-490 nm) was employed to visualise the external surfaces, mineral particles and other compounds, which had a different refractive index from organic matter.

The different optical series can be processed to obtain a single compound image (512 x 512 pixel series and 24 bytes per pixel) by means of different algorithms from the microscope software (Leica) and Imaris software package (Bitplane AG, Zurich). In the figure 3 we present images of a single optical sections and others processed by means of the following algorithms: i) Maximum intensity projection: two- 

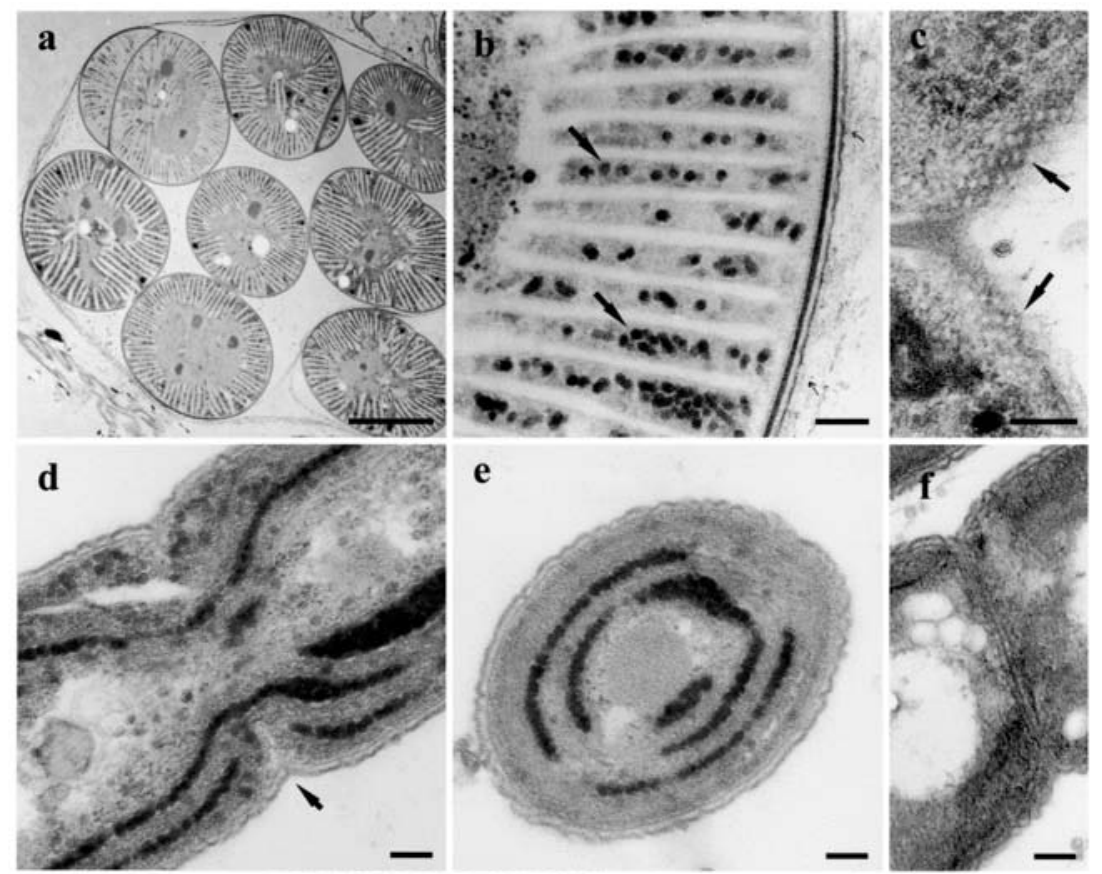

e
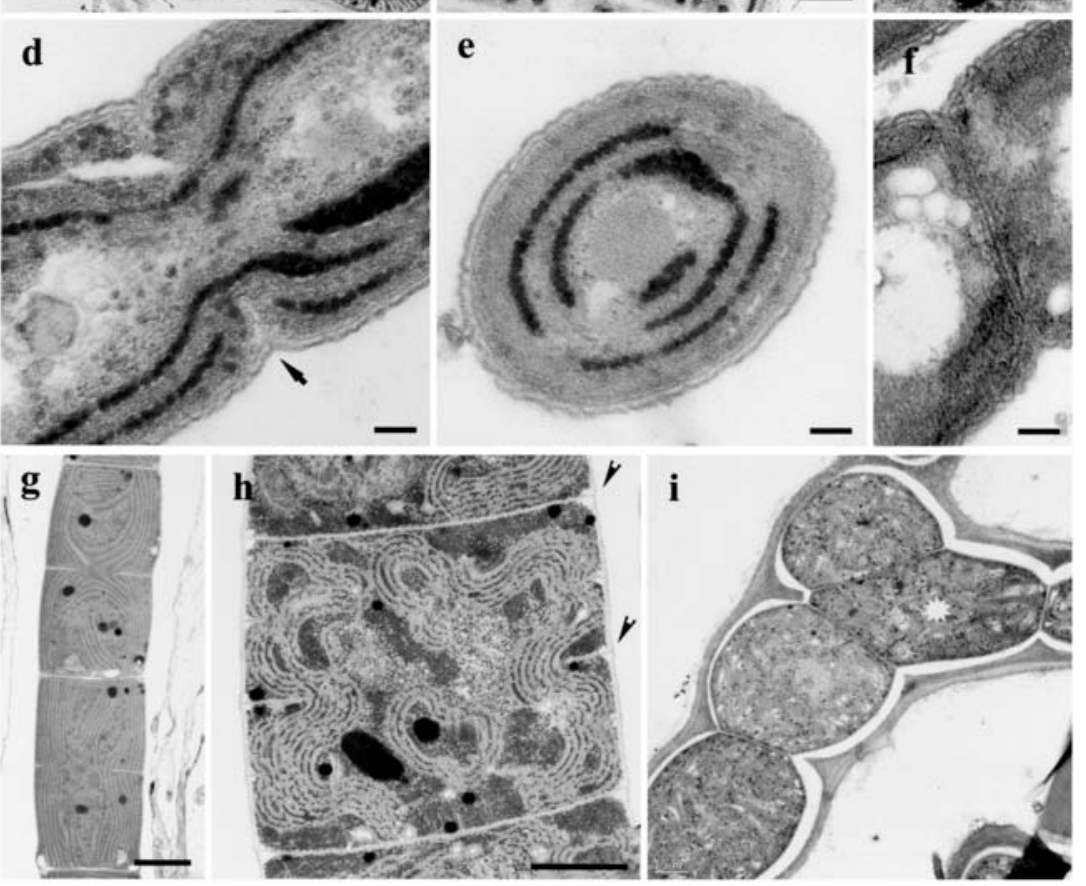

Figure 3. Transmission electron photomicrographs. a,b, Microcoleus chthonoplastes from a surface microbial mat. Rapid freeze fixation and freeze substitution. a, cross section through a bundle inside a common sheath. Scale bar $=2 \mu \mathrm{m}$. $\mathbf{b}$, enlarged view showing the mucilaginous covering, the Gram-negative cell wall and the radial arrangement of the thylakoids. Black spots between thylakoidal membranes are glycogen granules (arrow) Scale bar $=0.1 \mu \mathrm{m}$. c, M. chthonoplastes. Thin section in the septum region showing the rows of pores at both sides. Chemical fixation. Scale bar $=0.1 \mu \mathrm{m}$. d,e,f, Halomicronema excentricum from hipersaline ponds. Chemical fixation. d, longitudinal section. The outer membrane of the cell wall is not involved in the formation of the septum. A slightly constriction is found between cells along the trichome length (small arrow). Scale bar $=0.1 \mu \mathrm{m}$. e, cross section. The thylakoids are concentric and parallel to the cell wall. Scale bar $=0.1 \mu \mathrm{m}$. f, group of gas vesicles close to the septum. Scale bar $=0.1 \mu \mathrm{m}$. g, longitudinal thin section of a Oscillatoria lacus-solaris trichome. Chemical fixation. Thylakoids are disposed more or less parallel to the longitudinal walls. However, some of them cross the nucleoid area. Discontinuous cell division, daughter cells divide and grow into the mother cell size before the next division. Scale bar $=1 \mu \mathrm{m}$. $\mathbf{h}$, Lyngbya sp. Chemical fixation. Thylakoids are whorled or arranged in parallel groups. Cyanophycin granules are scattered among thylakoids. Continuous cell division, since a new septum formation began before the former one is finished (arrows). Scale bar $=1 \mu \mathrm{m}$. i, Fischerella sp. from a hypogean habitat. Chemical fixation. The trichomes can be either slightly constricted at the cell walls or torulose. Note the true lateral branching that originates from the change of division plane from transversal to longitudinal: intercalary cell (white asterisk) is in contact with three other cells. Scale bar $=1 \mu \mathrm{m}$. Microfotografias de transmisión. a, $b$, Microcoleus chthonoplastes procedente de la superfície de un tapete microbiano. Fijación mediante congelación y criosubstitución. a, Sección transversal de un haz de filamentos. Escala $=2 \mu m$. b, Visión longitudinal de la envoltura mucilaginosa, la pared celular Gram-negativa y la disposición radial de los tilacoides. Gránulos del glicógeno entre las membranas tilacoidales (flecha). Escala $=0.1 \mu \mathrm{m}$. c, M. chthonoplastes. Sección en la región del septo que muestra las filas de poros a ambos lados. Fijación química. Escala $=0.1 \mu \mathrm{m}$. d,e,f, Halomicronema excentricum de cubetas hipersalinas. Fijación química. d, Sección longitudinal. La membrana exterior de la pared celular no interviene en la formación del septo. Se observa una ligera constricción en los tabiques (flecha pequeña). Escala $=0.1 \mu \mathrm{m}$. e, Sección transversal. Tilacoides concéntricos y paralelos a la pared celular. Escala $=0.1 \mu \mathrm{m} . \boldsymbol{f}$, Grupo de vesículas de gas cerca del septo. Escala $=0.1 \mu \mathrm{m}$. g, Sección longitudinal de un tricoma de Oscillatoria lacus-solaris. Fijación química. Los tilacoides se disponen de forma más o menos paralela a la pared longitudinal. Sin embargo, algunos de ellos cruzan el área del nucleoide. División celular discontinua, una sola división intercalar por célula. Escala $=1 \mu \mathrm{m}$. h, Lyngbya sp. Fijación química. Tilacoides espiralados o en grupos paralelos. Gránulos de cianoficina distribuidos entre los tilacoides. División celular continua, más de una división intercalar por célula (flechas). Escala $=1 \mu \mathrm{m}$. $\boldsymbol{i}$, Fischerella sp. procedente de hábitats hipogeos. Fijación química. Tricomas torulosos o con una ligera constricción a nivel del septo. Fijarse en la ramificación lateral verdadera que origina un cambio de plano de división del transversal al longitudinal: la célula intercalar (asterisco blanco) está en contacto con tres células. Escala =1 $\mu \mathrm{m}$. 
dimensional compound image that integrates the maximum fluorescence intensities of each $\mathrm{x}$, $y$ point of all the optical series along the z-axis. ii) Extended focus: the image is divided into three frames that represent the maximum intensity projection for the $x-y, x-z$ and $y-z$ planes. iii) Simulated fluorescence processing (SFP): a three-dimensional simulation that enhances the fluorescence of surface layers and embosses all channels, as if they were illuminated from an oblique angle (Messerli et al., 1993).

Extended focus images of unmodified stone fragments (Fig. 3i), built with the maximum intensity projections of the $x-y, x-z$, and $y-z$ planes, evidenced gross spatial distribution of microorganisms, EPS and substratum, but also the disposition of microorganisms (e. g. erected vs. prostrate filaments) exhibiting the stratification of the biofilm.

These microscopy techniques (SEM, TEM and CLSM) complemented each other to build a complete physical and physiological description of the cyanobacteria and the communities they constitute.

\section{ACKNOWLEDGEMENTS}

This work was supported by EU Programme Energy, Environment and Sustainable Development in the frame of CATS Project, contract EVK4-CT-2000-00028. The facilities of SEM, TEM and Confocal Microscopy provided by the Scientific and Technical Services of the University of Barcelona are gratefully acknowledged.

\section{REFERENCES}

ASCASO, C., J. WIERZCHOS, V. SOUZA-EGIPSY, A. DE LOS RÍOS \& J. DELGADO RODRIGUES. 2002. In situ evaluation of the biodeteriorating action of microorganisms and the effects of biocides on carbonate rock of the Jeronimos Monastery (Lisbon). International Biodeterioration \& Biodegradation, 49: 1-12.
BETTAREL, Y., T. SIMENGANDO, C. AMBLARD, \& H. LAVERAN. 2000. A comparison of methods for counting viruses in aquatic systems. Appl. Environ. Microbiol., 66: 2283-2289.

GARCÍA-PICHEL, F., J. BELNAP \& S. NEUER. 2003. How much cyanobacteria? Estimates of total biomass and its distribution. Arch. Hydrobiol./ Suppl., 148. Algological studies, 109: 213-227.

GOLDSTEIN, J. I., D. E. NEWBURY, P. ECHLIN, D. C. JOY, C. FIORI \& E. LIFSHIN. 1981. Scanning Electron Microscopy and X-Ray Microanalysis. Plenum Press. New York and London.

HAUGLAND, R. P. 1999. Handbook of Fluorescent Probes and Research Chemicals, $7^{\text {th }}$ Ed. Eugene: Molecular Probes, Inc.

HAYAT M. A. 1989. Principles and techniques of electron microscopy. Biological applications. Macmillan Press LTD. Houndmills and London.

HERNÁNDEZ-MARINÉ, M., G. MARTINEZ, A. DOMINGUEZ, R. FONTARNAU \& N. CORTADELLAS. 2001. SEM studies of arborescent aerophytic biofilms. Use of acrolein and osmium vapour impregnation. In: Microscopy: 334-335, Universitat de Barcelona, Barcelona.

MCMULLAN, D. 1995. Scanning electron microscopy 1928-1965. Scanning, 17: 175-185.

NEU, T. \& J. R. LAWRENCE. 1997. Development and structure of microbial biofilms in river water studied by confocal laser scanning microscopy. FEMS Microbiology Ecology, 24: 11-25.

PAWLEY, J. B. 1995. Handbook of biological confocal microscopy. Plenum Press, New York and London).

PORTA, D., R. RIPPKA \& M. HERNÁNDEZMARINÉ. 2000. Unusual ultrastructural features in three strains of Cyanothece (cyanobacteria). Archives of Microbiology 173: 154-163.

QUINTANA, C .1994. Cryofixation, cryosubstitution, cryoembedding for ultrastructural, immunocytochemical and microanalytical studies. Micron, 25: 63-99.

ROLDÁN, M., E. ClAVERO, S. CASTEL \& M. HERNÁNDEZ-MARINÉ. 2004. Biofilms fluorescence and image analysis in hypogean monuments research. Arch. Hydrobiol./Suppl. 150. Algological studes, 111: 127-143.

URZI, C. \& P. ALBERTANO. 2001. Studying phototrophic and heterotrophic microbial communities on stone monuments. In R.J. Doyle (ed.), Methods in Enzymology 336: 340-355. San Diego CA. Academic Press. 
